\title{
The examination of spices used in the Ottoman palace cuisine
}

\author{
Seydi Yıkmış ${ }^{1}$ \\ Kübra Sağlam ${ }^{2}$ \\ Adem Yetim $^{3}$
}

\begin{abstract}
The human being has a vital prescription to eat and drink as much as the day-to-day process. This vital point constitutes the foundation stone of gastronomic tourism. In our globalized world, nations that express or offer their own values have become more successful. Therefore, the culture of Turkish food and nutrition refers as the key of national culture. Therefore, it is very important to examine the characteristics of the Ottoman cuisine to introduce food culture. Traditionally Ottoman cuisine, soups, meat dishes, olive oil vegetables, salads and spices used in desserts are important. Nowadays, people want to learn not only the sense of hunger but also the history of gastronomy (all components depending on cultural and environmental influences). It gives us great opportunities when it is told and applied to the history of that cultural gastronomy. These opportunities are making economic difference by strengthening the functions of gastronomic tourism. Due to the literature obtained in the study, it is thought that the inclusion of the spices in the Ottoman cuisine destinations in Turkey, which has a high potential for gastronomy tourism, will support sustainable development. In the study, was given informations about the characteristics of the spices used in Ottoman cuisine.
\end{abstract}

Keywords: Ottoman Cuisine; Gastronomy Tourism; Spices.

\section{Introduction}

In order for a place to become a tourism region, it must have characteristics that make up the tourism product. These features are; attractiveness, accessibility, activities, tourism operations and image (Kozak, 2006). Tourism is one of the important activities in the service sector that contribute to the economy. Domestic and foreign tourism activities bring income to the country's economy. In the sense that the three sides of our country are surrounded by seas, the seaside regions have a touristic attraction. However, natural, historical and ecological resources such as mountain, lake, plateau also constitute an important touristic potential (Gök \& Tuna, 2013). Gastronomic tourism is defined as visits to primary or secondary food producers, food festivals, restaurants and special areas where priority travel motivation is to taste a meal or produce a special meal (C. M. Hall \& Mitchell, 2001).

Due to the structural nature of tourism, a tourist does not benefit from only one element; On the contrary, it buys the 'ultimate product' which arises from a combination of many

\footnotetext{
1 Lecture, Namik Kemal University, School of Health Sciences, Department of Nutrition and Dietetics, syikmis@hotmail.com

2 Lecture, Istanbul Gelişim University, Istanbul Gelişim Vocational School, Food Technology Program, ksaglam@gelisim.edu.tr

${ }^{3}$ Lecture, Istanbul Gelişim University, Istanbul Gelişim Vocational School, Culinary Program, ayetim@gelisim.edu.tr
} 
geographical, economic and social elements and this product can show itself as an important factor in the formation of the tourist's holiday experience (Sari \& Kozak, 2005).

The use of plants as medicines in Anatolia or in other ancient settlements in history dates back to the previous years in B.C. It is thought that the Anatolian people have been using the plants since the Paleolithic. One of the oldest prescription patterns known in history belongs to the Hittites (Gürsoy \& Kahraman, 2004). They are aromatic herbal products that are added to spices, foods and drinks for different purposes (Üner, Aksu, \& Ergün, 2000). It is known that the spice was very valuable and precious in the 13th century and was used instead of money as a means of exchange in trades made. It can also be defined as the contribution of food to the discovery of new continents and new trade routes, which causes the nations to fight each other, and which brings eastern and western civilizations closer to each other (Yaldız, Kilınç, \& Ülküsever, 2010).

Spice is a product of eastern countries. In $3000 \mathrm{BC}$, the Chinese started trading spices based on sales of cinnamon, cardamom, ginger and turmeric. The spice trade, initiated by the Chinese, was later developed by the Arabs. Throughout history, all civilizations have been able to make use of the richness brought by the spices and have brought these riches to their countries through the "Spice Road". In the early days, spices were being transported from West Asia to the Black Sea and Near East countries by land. Until the 1400's, Arab and Indian merchants were transported by sea to the ports in the Red Sea. There were two ways to move to Mediterranean ports; The first one was shipped from India to the Persian Gulf, and then to the ports of Anatolia and Syria by caravans. Istanbul was the city where these goods were the most. The second road was again brought to the Suez from the Indian Ocean and the Red Sea by the ships, then from the caravans to the Mediterranean ports. Spice trade has been in Venodes for many years. But it has been moved to different dimensions with the beginning of the domination of the Ottoman Empire. The most important commercial spice was black pepper (Tayar, 2012). The Ottoman palace cuisine was indispensable in the spring, especially during the 18th and 19th centuries, black pepper was placed in almost all meat dishes. Central Asian nomadic people have been influential in the formation of a rich Turkish food culture using food in conjunction with the spring of South Asia (Ertaş \& Gezmen Karadağ, 2013). The commercial value of spices at the beginning of the 19th century had decreased due to the growth of spice-grown regions and the change of people's eating pleasures (Anonymous, 2017).

In this study, it was tried to contribute by informing about the spices as the destination attractiveness element of the Ottoman cuisine in gastronomy tourism by mentioning the characteristics of the spices which are most commonly used in the Ottoman cuisine.

\section{Spices used in Ottoman Palace Cuisine}

\subsection{Nigella}

Nigella; It is a blue flowering herbaceous plant which grows in the Mediterranean region and Anatolia, A. Nigell; Define the crowfoot family. Nigella sativa Linn seeds. (Ranunculaceae), commonly known as blackcurrant or barnyard grass, is used as a herbal remedy in the world for a range of conditions, treatment and prevention, including asthma, diarrhea and dyslipidaemia. Seeds contain fixed and volatile oils, proteins, alkaloids and saponin. Nigella oil is a reddish chestnut oil obtained by squeezing citrus seeds. Seed / oil has analgesic, anti-inflammatory, antibiotic and antineoplastic activity effects, reducing oil blood pressure and increasing respiration (Ali \& Blunden, 2003). Seeds contain fixed oil (30-45\%), essential oil, bitter and saponin. It has power transmitter, stimulant, urine and milk enhancer, appetizer and menses exterminating effects. Some active ingredients of seeds and extracts; Hypoglycemia, hypertension, antiasthmatic, antibiotic, antiparasitic, antioxidant and anti-cancer effects have been determined (Kalus et al., 2003; Randhawa \& Alghamdi, 2011). 
Yıkmış, S., Sağlam, K., \& Yetim, A. (2017). The examination of spices used in the Ottoman palace cuisine. Journal of Human Sciences, 14(1), 1000-1016. doi:10.14687/ihs.v14i1.4508

\subsection{Sweet Basil}

Ocimum includes single or perennial species belonging to the family Labiateaea. Among the Ocimum species, Ocimum basilicum L. is the most economical species. Basil (Ocimum basilicum L.) originating in South Asia, especially India, has spread to the tropical and temperate regions. Today, more cultures are being made in France, Italy and Spain (Çelebi, 2010; Erken, Sönmez, Sancaktaroğlu, \& Bayram, 2015). Basil (Ocimum basilicum L.) is a pleasant fragrance in the form of a single annual bush, with its own unique herbal medicine and spice plants (Karakuzu, 2015). In some regions, especially in the east, purple-colored figures are common and named as basil (Erken et al., 2015). Basil is grown in all the Mediterranean countries and Turkey, with India being the mainland. Leaves, bows and seeds of the plant are nervous soothing, digestive facilitator, urine enhancer and gas extractor. It is also used to flavor food such as mint. It is used as an urinary tract antiseptics and also it is used as a stomach sedative and gas expectorant (Ghasemzadeh et al., 2016; Uzun, 2007).

\subsection{Rose Geranium}

Sardinia, Pelargonium (Pelargonium Graveolens, Pelargonium Radicula, Pelargonium Rose) family, Geraniumceae family leaves are fragrant ornamental plants. The thorn species, which is used as an important fragrance in soap and perfumery, is grown in India and North Africa (Morocco, Algeria). The wild flowers of the Pelargonium Endlicherianum grown in the Central and Eastern Anatolian mountains are used as wolf-lowering agents. It is cultivated as ornamental plant all over the world with hybrids with some species of South African origin. This plant is used in traditional medicine in South Africa for a long time. Bronchitis, sinusitis, angina (sore throat), nasal discharge due to viral infections and pharyngitis have been found to be effective. Studies in some species have shown that free radical scavenging and antioxidant effects on antiinflammatory and oxidative stress (Öz, 2013; Rafiq et al., 2016; Ünlü \& Aysan, 2016).

\subsection{Thyme}

Thyme (Thymus vulgaris) plant is in the Lamiaceae family. Thyme has a unique smell, especially thymol and carvacrol. Thyme plant is known to have antimicrobial, digestive stimulant, antispozmadic and antioxidant effects. It is known that antimicrobial effects of thymol and carvacrolin are found especially in thyme essential oils (Ertürk, Çelik, Kaygusuz, \& Aydın, 2010). It is also used as a spice. Cold tea, bronchitis, colds, flu and coughing against drinking tea. In addition, tea is given to small infants as an intestinal gas remover (Türkan, Malyer, Özaydın, \& Tümen, 2006). In recent years, antioxidant and antimicrobial effects in food storage and prolongation of shelf life have been used to prevent aggravation and deterioration in food (Kerekes et al., 2016; Quesada, Sendra, Navarro, \& Sayas-Barberá, 2016).

\subsection{Black Pepper}

It is a tree that grows in the hot regions of the world and is used as a spice. This tree is defined as the bitter and fragrant fruit of a small pea. This fruit is dried after being ground and prepared by grinding. In black pepper there is a crystalline substance called piperine; As well as a very bitter greasy green oil, a balsamic volatile oil, a gummy substance, malic and uric acid, and various salts. A bitter resin is extracted at the burning point from the black pepper dissolved in alcohol. Black pepper has various irritating, appetizing effects at different ratios. Black pepper is one of the most consumed spices in Turkish cuisine. Ottomans began to dominate the Mediterranean trade XVI. and XVII. In the 19th century, the black pepper, which came with other spice varieties, was first used in palace and mansion cuisines because it was an expensive item; Then spread to the 
public as well. Today it is the main flavor ingredient used in many meat dishes, rice, pasta type pastries, some stuffed mortars, soups, some pastries, some sauces and sauces, grain or powder. It can be used by joining the spice during the cooking of your meal or after sprinkling it on it. When consumed in small quantities, it has an appetizing effect (Büyük Larousse Sözlük ve Ansiklopedisi, 1986a). Black pepper (Piper nigrum) is one of the most widely used spices. Black pepper is used not only for medical and other purposes like human dietaries, but also as a preservative and perfume. Black pepper, its essence, large or active principle, piperine, many physiological effects have been reported in recent years. Dietary piperine improves digestive capacity by stimulating digestive enzymes in the positive pancreas, and greatly reduces food gastrointestinal transit time. Piperine has been shown to protect against oxidative damage in vitro studies or to protect water from free radicals and reactive oxygen species. The effects of antioxidant molecules and antioxidant enzymes have been proven in black pepper or piperine therapy. The most extensive attribute of Piperine has been the inhibitor effect on enzymatic drug biotransforming responses in the liver. Piperine has been documented to develop a number of treatments with treatments, as well as a number of chromium and iron should be given. Piperine has been found to have anti-mutagenic and anti-tumor effects, although it is non-genotoxic (Derosa, Maffioli, \& Sahebkar, 2016; Srinivasan, 2007). Piperine is a non-genotoxic agent that has anti-mutagenic and anti- Are used to treat rheumatic diseases (Chaudhry \& Tariq, 2006; Karsha \& Lakshmi, 2010).

\subsection{Pine Kernel}

Pinus pinea (Pinus pinea) is a kind of forest tree with a wide hill and pile root system (Batur, 2015; Gönültaş \& Balaban Uçar, 2012), which forms natural and artificial forests on the Mediterranean climate belt. Side products other than pine nuts are also obtained from the peanut pine tree. These; Conifer and firewood are used as firewood. As a by-product, the material of turpentine used in the paint and chemical industry is obtained from the resin of this tree. Peanuts are preferred in the forest and furniture industry because the body of the pine tree is of good quality (Çetin, 2003). The composition of mature seed of peanut pine (Pinus pinea) contains fixed fat, protein and cellulose. The paste obtained by crushing with honey is used as a force transmitter (Büyük Larousse Sözlük ve Ansiklopedisi, 1986b).

\subsection{Mint}

Mentha (Mentha spicata L.) contains ethereal oils, especially menthol and tannin, which is a vegetable-edible vegetable in the class of medical plants. Mint, which is fresh and dry in our country, is also used as tea at the same time. It is widely used in various food industries and in the treatment of various diseases due to antiseptic properties with its widespread use in perfume, drink, chewing gum and medicine industry (Kocabiyık \& Demirtürk, 2008). Mentha species are commercially cultivated in many countries due to the precious value of volatile oil. It has medicinally effective spasm and degasser, antimicrobial, midwife, refreshing, stimulant and diuretic effects and is widely used in spices and herbal teas. Menthol is the most abundant natural source of mint oil medicine, food and cosmetics industry and it is rich in pulegon (Ertürk et al., 2010; Özgüven \& Kırıc1, 1999). Mint tea made with lemon is used against colds, flu, colds and nausea. Spread as a spice (Türkan et al., 2006). Essence extracted from the leaves is added to toothpastes and chewing gum as an odor. In pharmacopoeia, there are about ten mints registered. From the body and leaves of many people (M.Piperita), water vapor extracts the essence of mint, a volatile oil. This essence called Naneruhu is taken as a light antiseptic, refreshing, nausea-sicting, dropping 2-10 drops onto a piece of sugar. Strong smelling, burning, tasty liquid. It contains 4090\% menthol according to its origin. Garden nanesinin shade-dried leaves contain resin, tannin 
Yıkmış, S., Sağlam, K., \& Yetim, A. (2017). The examination of spices used in the Ottoman palace cuisine. Journal of Human Sciences, 14(1), 1000-1016. doi:10.14687/jhs.v14i1.4508

and essential oil. 4-5\% infusion is used as a nausea-blocker, gas expectorant, odor and power transmitter by drinking two glasses a day (B̈̈ÿ̈̈k Larousse Sözlük ve Ansiklopedisi, 1986).

\subsection{Sumac}

The sumacs are small type trees with bushes, small buds. Fruits are reddish and consist of single core. Sumac has been produced in Spain, Turkey, some Mediterranean and Arab countries since the 1970s. (Latin name: Rhus coriaria Familia: Anacadiaceae) is a type of spice commonly used in Turkey and the Middle East countries. Sumac is used to give the food a sour taste after being harvested and then dried and ground. In addition, the water extract of sumac granules is used as sauce in salads and some dishes (Özkanlı \& Tekin, 2006). The natural spread of the Rhus genus systematically belongs to the Anacardiaceae family, and in the west it spreads widely from Canada to Tajikistan in the east (Yücedağ, Gültekin, \& Pirlak, 2010). Rhus coriaria: Several studies have been carried out on the antimicrobial effects of sumac and have been found to be antimicrobial effective. It has been determined that the antioxidant capacity is high (Kosar, Bozan, Temelli, \& Baser, 2007; Nasar-Abbas \& Halkman, 2004). .

\subsection{Cinnamon}

Cinnamon (cinnamomum); Belongs to the family of lauraceae, whose motherland is South and Southeast Asia. This aromatic, low-tall tree that does not plow its leaves; Is not growing in Turkey due to the inadequate climate. Cinnamon consumed in Turkey is mainly imported from Indonesia, Singapore and Vietnam (Ö. Aydın, 2011; Shylaja \& Peter, 2006). Cinnamon shell with aromatic flavor is mostly found in Egyptian and Turkish cuisine. It is used in meat and fish dishes in England cuisine, cinnamon cake and pastry desserts in American cuisine, as a sweetener in meat dishes, rice dishes and garam masala in Indian cuisine as well as curry powder. It is a plant that everyone uses especially in desserts, syrups, pilafs and teas with its pleasant smell and delicious taste. It is used as a sweetener in pastries, cakes and cookies and is also frequently used as an indispensable drink in winter. Cinnamon, which we use in our cuisines as a flavor and aromatic scent, has been used for therapeutic purposes since ancient times. In recent years, scientific research has shown that the cinnamon has antimicrobial, antioxidant and lipid-lowering effects. Phytotherapy approaches, which are very popular in recent times, are also in the treatment of coronary heart disease and spices such as fennel, thyme, rosemary and cinnamon are used among the people (Dhuley, Safdar, Khan, Khattak, \& Anderson, 1999; Özbek et al., 2016). It is also known that cinnamon shells have a psychoactive effect in the case of smoke inhalation.1950-1970 has been shown to be one of the hallucinogenic substances used by American hippies (Gürson \& Özçelikay, 2005).

\subsection{Cilantro}

In Turkey, coriander is a spice plant of the Umbelliferae family, known by names such as Ashtoot, Kuzbere (Baytop, 1994). Coriandrum L. is represented by 2 varieties (Davis, 1988) and 2 varieties in the genus Turkey Flora. C sativum L. var. Microcarpum DC. It is known as small granular coriander (Wagner \& Bladt, 1996; Zeybek \& Zeybek, 1994). Mardin, Gaziantep, Burdur, Erzurum, Denizli, such as our agriculture is made (Akgül, 1993). Fresh leaves of coriander seeds are used in various salads and roots are used as spices in meals. At the same time refreshing is also appetizing with pleasant smell. It is used in the finishing of meat dishes and olive oil. It is used for the treatment of head and teeth pain, dizziness, pharyngitis, weakness of the heart and stomach, hemorrhoids, hives and pimples (Kara, 2016; Şanlı, Karadoğan, \& Daldal, 2012). Cicinia has brought the Romans to Europe using meat to make brine. The coriander, which has been named in the Bible and at One Thousand Nights, was used as a medicine in ancient 
Yıkmış, S., Sağlam, K., \& Yetim, A. (2017). The examination of spices used in the Ottoman palace cuisine. Journal of Human Sciences, 14(1), 1000-1016. doi:10.14687/jhs.v14i1.4508

Mesopotamia, Egypt (1500 BC). The Chinese believed that coriander had overcome immortality. In the Middle Ages (5-15 centuries), aphrodisiac love was used as an elixir. Small coriander fruits are covered with sugar and a special candy called 'coriander sugar' is produced (Doğan \& Akgün, 1987).

\subsection{Cumin}

Cumin (cuminum cyminum L.) is a herbaceous plant variety of $40-60 \mathrm{~cm}$ in length, which opens in May and June, white and pink flowers, from the family of parsley gills. The mainland is the Eastern Mediterranean and the Middle East. In July, the fruit grow ripe. It has a special scent of its own. It is an important spice plant in terms of volatile oil. Cumin is the most cultivated countries in the world: Iran, Uzbekistan, Tajikistan, Turkey, Morocco, Egypt, India, Syria, Mexico and Chile. Cumin is one of the plants that can be used for shortening of fallowing time and shortening of fallow fields by the lack of water and nutrient requirement. It is a medicine and spice plant cultivated most in Central Anatolia region in Turkey. Cumin fuels contain 15-25\% protein, 2-5\% essential oil, 10-23\% fixed fat, tannin, flavonoid, resin and gum (Akgül, 1993). (Antiinflammatory effect), pharyngitis (antiinflammatory effect), abdominal pain (analgesic and myorelaxant effect), rheumatism (antiinflammatory effect), tooth pain (analgesic and antiinflammatory effect), diabetic retinopathy Antispasmodic effect), diuretic and urinary tract obstruction (anti-inflammatory effect) (Gürsoy \& Kahraman, 2004; Janahmadi, Niazi, Danyali, \& Kamalinejad, 2006; Pamuk, 1998). Cumin seed sweetener is one of the popular spices used for traditional dental pain (Thippeswamy \& Naidu, 2005).

\subsection{Gum}

Located in the middle of three continents due to its geographical location, Turkey has different characteristics due to its center of these three continents both in terms of climate and land. These different features bring with it species diversity and richness. One type of this richness is the mastic tree (pistacia lentiscus L. var chia), which spreads only on the Chios Island of Greece and on the shores of the Çeşme. Gum; Which is also known in the time of the Pharaohs and which is cultivated and traded on the island of Chios since the antiquity and which has been traded, taken for protection by law, applied to the holy books which are known as the oldest seabed of the World (Ak \& Parlakc1, 2009; Boztok \& Zeybek, 2003). The gum tree is an important raw material of the pharmaceutical and food industry today. There is also ecological value due to its ability to withstand drought, then its ability to renew itself quickly (Mascarello, Fascella, Zizzo, Mantovani, \& Ruffoni, 2007). As a sweetener, in cakes, in ice cream, in milk desserts, in the production of alcoholic drinks, especially in the production of liquor and ouzo, mastic is widely used. Mastic gum is also used to give consistency to spices and different sauces. Mastic resin is the main component of puddings and ice creams, making them light white in color (Akdemir, Tilkat, Onay, Kllıç, \& Süzerer, 2013).

\subsection{Aniseed}

Anise (Pimpinella anisum L.) is a one-year, aromatic plant of the Apiaceae family from the Apiles family. The anise is a very old cultivated plant originating from the Eastern Mediterranean. Turkey, Italy, Mexico, Spain, Germany, India, Central and South America (Doğramac1 \& Arabac1, 2010). Among the people, Anison is also called Enison, Nanahan (Gaziantep) and Raziyanei-rumi (Baytop, 1999). Anise has strong medicinal properties that stimulate digestion, degasifiers, appetizing, fragrance and immobility stimuli. China and India have been using this plant for many years. Indians chew aniseed seeds after each meal, indicating that the anion has an effect on the digestive system. Anise is used in the preparation of some alcoholic beverages (raki), meat, poultry and fish, pastries, sweeteners in donuts and snake bites for treatment purposes. The 
distinctive, lasting and beautiful fragrance of the anise fruit is indispensable for the perfumery industry. In addition, there are more essential oils in the aniseed fruit than in the seeds of Cirque du Soleil. Aniseed volatile oil medicine and pharmacy; Antispasmodic, antioxidant, antimicrobial, insecdicidal and antifungal properties (Özcan \& Chalchat, 2006; Tirapelli et al., 2007; Zeybek \& Zeybek, 1994). Anason is used medically in dissipative complaints, in the treatment of influenza and as a mild sputum remover (Blumenthal, 2000).

\subsection{A blend of powdered thyme(Zahter)}

Thymus, Thymbra and Origanum species belonging to lamiaceae family are known in Turkish as thyme in general. There are about 40 species of Thymus genus in Turkey (Kiz1l, Toncer, Diraz, \& Karaman, 2015). Thymbra spicata from the same family is usually called Kara thyme and in the Southeastern Anatolia region this dried plant leaves and flowers are known by the names of sater and they are drinking as tea due to its antiseptic and stimulating effect. Almost entirely in Turkey, Zahter of Gaziantep and Antakya province is famous and known for being like a cape. With a sharp smell and a bitter tiger, the bush is a bush in April and May with a bushy appearance. Apart from being a plant, Zahter adds a distinct flavor to every meal with its different flavor and smell. Dried and put into a bowl with a grinded olive oil, poultry, poultry and fish dishes, fresh leaves can also be consumed in salad form. Especially during the Ottoman period, breakfast has become indispensable. Zahter plant; Zahter tea, zahter oil, zahter paste, zahter soap and zahter cream are produced. In the composition of the zahterine there is $1.2-1.8 \%$ essential oil. Essential oils include carvacrol (Baytop, 1984). It is used as stimulant of blood circulation, strengthening of the nervous system, constipation, digestive, stomachic, diuretic, antiseptic, stimulant, carminative, diaphoretic, dispeptic, sedative, antihelmintic and expectorant (Fak1l1, 2010).

\subsection{Sweet Marjoram}

Marjoram has a wide distribution area. South of Greece, Crete and many other Greek islands, and south and west of Turkey (Ietswaart, 1980). It is used in meat and meat products, pizza, soup, salad and many food products. Marjoram oil and oleoresin are also used in alcoholic and non-alcoholic beverages as well as in cosmetic products. Kekinin's water distillation product, volatile oil and water (thyme), is used because of its bile-enhancing properties in endocrine disorders such as stomach, intestinal disorders (abdominal pain, nausea, indigestion) and diabetes (S. Aydın, Öztürk, \& Başer, 1993). It was found that marjoram volatile oil delayed the fat oxidation of raw and cooked chicken, and had strong antioxidant activity at low concentration (100 ppm) (Botsoglou, Christaki, Fletouris, Florou-Paneri, \& Spais, 2002; Ruberto, Baratta, Sari, \& Kaâbeche, 2002).

\subsection{Cardamom}

Kakule, known in Arabic and Persian as "Hêl", is known as "cardamom" in English, and West and South India are large-leaf perennial plant breeds that grow in the hot regions of Southeast Asia (Agnihotri \& Wakode, 2010). Cardamom (Elettaria cardamomum) is a family member of the family Zingiberaceae, traditionally used in food and medicine (Anwar, Abbas, Alkharfy, \& Gilani, 2016). Its seeds are lentil-shaped and large in size, with a reddish brown color and a sharp smell. It is used as a spice because of its pleasant taste and smell. It can be used in salted foods such as cardamom, meat and pulses dishes, spicy rice, baked goods and fish. It also gives a nice flavor to milky desserts, cookies and cakes (Akrayi, 2012). In many cultures tea is used to add flavor, especially coffee (Ağaoğlu, Dostbil, \& Alemdar, 2006). It has effects like appetizer, memory booster and gas extractor. Antimicrobial effects have been observed in some studies (A ğaoğlu et al., 2006; Parthasarathy \& Prasath, 2012). 


\subsection{Clove}

The scientific name of carnation is Syzygium aromaticum. The carnation is obtained from the flower of Sysygium aromaticum, and the blossoms are obtained from the plant of Dianthus petraeus. Its homeland is Indonesia and used as a spice in all world cuisines (Adefegha \& Oboh, 2012). The main components of caraway oil are generally classified as eugenol, $\beta$-caryophyllene, $\alpha$-humulene and humulene epoxide according to their proportions. Eugenol, a fragrant, strong antiseptic and analgesic substance in carnation oil, can vary from $68 \%$ to $94.4 \%$ depending on the plant material and extraction method (Gill \& Holley, 2003; Juliani et al., 2006). In addition to antimicrobial, antioxidant, antifungal and antiviral activity, carnations also have antiinflammatory, cytotoxic, insect repellent and anesthetic properties (Aguilar-González, Palou, \& López-Malo, 2015; Chaieb et al., 2007; Pilar Santamarina, Roselló, Giménez, \& Amparo Blázquez, 2016). Antimicrobial activity of volatile oils and extracts of 15 different plants and spices has been investigated and classified according to their effect level. Clove was the most effective spice group in this order (Zaika, 2007). Consumption of compounds such as carnation parent compounds can help to prevent oxidative damage in vivo, such as lipid peroxidation, which is associated with many diseases including cancer, arteriosclerosis, diabetes, and immunodeficiency (Lee \& Shibamoto, 2001).

\subsection{Fennel}

Fennel is an important medicinal and aromatic plant (Pavela, Žabka, Bednář, Tř́íska, \& Vrchotová, 2016). An important spice plant of the Apiaceae (Umbelliferae) family, is the homeland of Western Asia and the Mediterranean countries (Uzun, Kevseroğlu, Özçelik, \& Yılmaz, 2012). It is used as a sweetener in soups, breads, pasta, meat and meat products, dairy desserts, fish, pickles and salads. In addition to being consumed as a vegetable or condiment when fresh, liquid extracts prepared from roots and seeds are also used in soft drinks, ice creams, sugary products and vinegar (Akgül, 1993; Kaya, Yllmaz, \& Telci, 2000; Şanlı et al., 2012). It is also commonly used in fennel liqueurs, breads, fish, cucumbers and cheeses (Damjanovic, Lepojevic, Zivkovic, \& Tolic, 2005). As a matter of fact, fennel seeds have been widely used in herbal tea forms, although they have been used for various purposes in recent years (Baranska, Schulz, Rosch, Strehle, \& Popp, 2004). The use of cough and bronchite in the digestive (dispeptic) disorders of the refinery is approved by the European Commission (Blumenthal, Goldberg, \& Brinckmann, 2000; Gruenwald, Brendler, \& Jaenicke, 2004).

\subsection{Estragon}

Tarhun (Mohammad Reza, Hamideh, \& Zahra, 2015), whose Latin name is 'Artemisia dracunculus', is the homeland of Siberia and has spread all over Eurasia. It has a very nice taste and smell. Especially the green and tomato salad adds a pleasant flavor. Used in various sauces. It holds its salt, pepper and sirkenin with its beautiful smell (Binici, 2002). It has an important place among the spices used to sweeten the dishes in the world, especially the French cuisine with its sharp smell and different flavor. Tarhun otu exhibits a wonderful harmony with chicken, fish, eggs, salad, potatoes and cream. Tarhunun leafy branches are rich in iodine, mineral salts, vitamins $\mathrm{A}$ and $\mathrm{C}$. Its composition contains essential oils (0.4-0.8\%), tannins and flavonoids, bitter, iodine, vitamins A and C (Gürpinar Y., 2012). Tarhun essential oil contains methyl ethers, such as osmine, myrsene, $\alpha$-pinene, $\beta$-pinene, camphor, limonene and linalool (Hassanzadeh, Tayarani Najaran, Nasery, \& Emami, 2016). 
Yıkmış, S., Sağlam, K., \& Yetim, A. (2017). The examination of spices used in the Ottoman palace cuisine. Journal of Human Sciences, 14(1), 1000-1016. doi:10.14687/jhs.v14i1.4508

\subsection{Mustard}

Wild mustard (Sinapis arvensis L.) (Cruciferae), which has more than 3,000 species in 350 genera in the family of Brassicaceae (Cruiferae), grows as weeds in cultivated plants (Price, Palmer, \& Al-Shehbaz, 1994). It is cultivated in third world countries and is known as the origin of black mustard (Akgül, 1993). Mustard is a natural antioxidant nutrient. For example, the extract has radical scavengers such as galic acid, quercetin, ferulic acid and caffeic acid. It is used as sweetening agent in foods. Medically, rheumatism and joint pain are used in the treatment of liver disease and throat tumors (Rajamurugan et al., 2012). Antifungal, antifungal, antiviral and antioxidant properties of mustard essential oil have been investigated in some studies (Chen \& Liu, 2016; Gilles, Zhao, An, \& Agboola, 2010; Mattson et al., 2011; Olaimat \& Holley, 2016; Prakash et al., 2011; Turgis, Han, Caillet, \& Lacroix, 2009).

\subsection{Safflower}

Aspir (Carthamus tinctorius L.) (C. Hall, 2016), a member of the family Compositae / Asteraceae, is grown for seeds which are essentially derived from edible oil and used as bird seeds (Eryılmaz, Cesur, Yeşilyurt, \& Aydın, 2014). Aspir seeds contain 25-37\% fat. Aspiration oil is a vegetable oil with the highest linoleic acid content (73-79\%) among known oils. This increases the quality of aspiration oil both in terms of quality and human nutrition (Nas, Gökalp, \& Ünsal, 1992). The main reason for consumption of aspirated flowers as tea in China is the presence of amino acids, mineral antioxidants and certain vitamins (B1, B2, B12, C and E) in the flower (Babaoğlu, 2006; Mündel, 2008). Aspir has been proven medically to provide more oxygen to tissues by increasing blood flow in the veins, reducing high blood pressure in women during menstrual periods, cardiovascular disorders and trauma-induced swelling and pain treatment (110). In Turkey, aspir (also known as hasp) flower is used to color some foods. In Turkey's Southeastern Anatolia Region (Diyarbakir and its environs), aspiration flowers in yellow color are used in pilaf and it is ensured that the rice is yellow in color (Babaoğlu, 2014).

\subsection{Saffron}

From the family of saffron (Crocus sativus), it is an onion culture plant and the spice obtained from this plant (Baytop, 1999; Mcgimpsey, Douglas, \& Wallace, 1997). Saffron, one of the most valuable spices in the world, is grown in Southwest Asia, indigenous peoples and in Southeast Asia, Turkey, Iran, India, Spain and Greece (Ahmed, Anwar, Al-Sokari, Ansari, \& Wagih, 2016). Saffron contains 150 "volatile and aroma-bearing compounds (Vurdu, Şaltu, \& Ayan, 2002). Most of these are carotenoids, including zeaxanthin, lycopene, and various $\alpha$ - and $\beta$ carotene. However, the saffron golden yellow-orange color gives $\alpha$-crosin (Baytop, 1999; Maggi et al., 2010). Pycrocrine is a sweetener and improves the flavor of your food, especially when used in meals (Baghalian, Sheshtamand, \& Jamshidi, 2010). Since ancient times, saffron has been regarded not only as a spice but also as a healing and protective substance for diseases and even sacred for its color at various times (Baytop, 1999). Safran has been found by modern medicine to have anticarcinogenic (cancer suppressant), anti-mutagenic (mutation-inhibiting), immunomodulating and antioxidant-like properties (Abdullaev, 2002; Dalby, 2000).

\subsection{Daphne}

Daphne family has 2200 species. Laurel plant (Laurus nobilis L.) is grown on the southern European and Mediterranean coasts in many warm temperate regions of the world (Izzaddeen, 2015). In Defnein's composition; Tannin and 1-4\% fragrant essential oil (Karaoğul, Ertaş, Altuntaş, \& Alma, 2011). Especially in volatile oil, the active substance is 35-50\% 1.8 cineole 
Yıkmış, S., Sağlam, K., \& Yetim, A. (2017). The examination of spices used in the Ottoman palace cuisine. Journal of Human Sciences, 14(1), 1000-1016. doi:10.14687/jhs.v14i1.4508

substance (Şafak \& Okan, 2004). In some studies antimicrobial properties of bay volatile oil have been investigated (Basak \& Candan, 2013; Evren \& Tekgüler, 2011; McIntosh, Newbold, Losa, Williams, \& Wallace, 2000; Smith-Palmer, Stewart, \& Fyfe, 2002). Dried leaves are generally used in canned foods, spices in soups, meat and fish, in canned fish to preserve the freshness of the fish and to smell it (Bozkurt, Yaltırık, \& Özdönmez, 1982). Antiseptic, antirheumatic, diuretic, otic and stomach pain relieving as traditional treatment; Dry fruits are used as sweeteners in foods, dry leaves in tea, volatile oils in soap making, and food and cosmetic industries as smell (Baytop, 1999). It has been reported that antioxidant activity can be used as an alternative to synthetic food additives (Hinneburg, Damien Dorman, \& Hiltunen, 2006).

\subsection{Ginger}

Ginger (Zingiber officinale Roscoe); a tuber-rooted yellowish plant that lives and grows in the geographical areas of the tropical climate (Kaplan, 2005). Widely used in many parts of the world, ginger has been used for centuries as a traditional spice or food aid (Jakribettu et al., 2016). Age and dried ginger are traditionally used to treat stomach pain, diarrhea, vehicle stiffness and have an appetizing effect. Roman, Chinese, Greek and Ottoman medical records indicate that ginger is used as a medicinal plant (Jakribettu et al., 2016; Konuklugil \& Özçelikay, 2004; Marx et al., 2014). Ginger contains antioxidant phenols, vitamin C, beta carotene, flavonoids and tannins. Gingerol, zingerone and shogaol are the most important phenolic compounds (Jakribettu et al., 2016; Park \& Pezzuto, 2002). It has digestive facilitating, appetizing, antioxidant and antiseptic properties (Konuklugil \& Özçelikay, 2004).

\section{Conclusion and Discussion}

Culinary culture constitutes an important part of the cultural values of an country. It is necessary to increase the number and capacity of gastronomy establishments that are working for the organization of gastronomic tourism, taking initiatives for the ownership of gastronomic tourism by the local people and promoting Turkey to strengthen the tourism awareness of the people. It would be useful to make informative presentations about the Ottoman cuisine for local people. Promotion and advertising activities need to be emphasized to improve gastronomic tourism. Introducing local products specific to the Ottoman cuisine at national and international fairs and concrete presentation of the historical, natural and cultural attractions of the Ottoman Empire during tourism fairs will affect the economy and image of Turkey in terms of marketing of tourism and spices sales.

Within the framework of development plans in Turkey, gastronomic tourism is emphasized in the studies to spread tourism to 12 months rather than seasonal. In this context, gastronomic tourism is important in terms of many destinations in Turkey as well. The Ottoman cuisine, which is among the richest cuisines in the world, has come to the conclusion that it will provide great contribution to the branding of destinations with an accurate positioning and an attractive image to be created.

\section{References}

Abdullaev, F. I. (2002). Cancer Chemopreventive and Tumoricidal Properties of Saffron (Crocus sativus L.). Experimental Biology and Medicine, 227(1), 20-25.

Adefegha, S. A., \& Oboh, G. (2012). In vitro inhibition activity of polyphenol-rich extracts from Syzygium aromaticum (L.) Merr. \&amp; Perry (Clove) buds against carbohydrate hydrolyzing enzymes linked to type 2 diabetes and $\mathrm{Fe}(2+)$-induced lipid peroxidation in rat pancreas. Asian Pacific Journal of Tropical Biomedicine, 2(10), 774-81. https://doi.org/10.1016/S2221-1691(12)60228-7 
Yıkmış, S., Sağlam, K., \& Yetim, A. (2017). The examination of spices used in the Ottoman palace cuisine. Journal of Human Sciences, 14(1), 1000-1016. doi:10.14687/ihs.v14i1.4508

Agnihotri, S., \& Wakode, S. (2010). Antimicrobial activity of essential oil and various extracts of fruits of greater cardamom. Indian Journal of Pharmaceutical Sciences, 72(5), 657. https://doi.org/10.4103/0250474X.78542

Aguilar-González, A. E., Palou, E., \& López-Malo, A. (2015). Antifungal activity of essential oils of clove (Syzygium aromaticum) and/or mustard (Brassica nigra) in vapor phase against gray mold (Botrytis cinerea) in strawberries. Innovative Food Science \& Emerging Technologies, 32, 181-185. https://doi.org/10.1016/j.ifset.2015.09.003

Ağaoğlu, S., Dostbil, N., \& Alemdar, S. (2006). Antimicrobial Effect of Seed Extract of Cardamom (Elettaria cardamomum Maton). Yü̃üncü Yal Üniversitesi Veteriner Fakültesi Dergisi, 16(2), 99-101.

Ahmed, N., Anwar, S., Al-Sokari, S. S., Ansari, S. Y., \& Wagih, M. E. (2016). Saffron Crocus (Crocus sativus) Oils. In Essential Oils in Food Preservation, Flavor and Safety (pp. 705-713). Elsevier. https://doi.org/10.1016/B978-0-12-416641-7.00080-8

Ak, B. E., \& Parlakc1, H. (2009). Pistacia lentiscus in the Mediterrranean Region İn Turkey. In ISHS Acta Horticulturae 818: I International Symposium on Pomegranate and Minor Mediterranean Fruits (pp. 77-82). https://doi.org/10.17660/ActaHortic.2009.818.10

Akdemir, Ö. F., Tilkat, E., Onay, A., Kılınç, F. M., \& Süzerer, V. (2013). Geçmişten Günümüze Sakız Ağac1 Pistacia lentiscus L. Batman University Journal of Life Sciences Batman Üniversitesi Yasam Bilimleri Dergisi, 3(2), 1-28. Retrieved from http://www.yasambilimleridergisi.com/makale/pdf/1398879932.pdf

Akgül, A. (1993). Baharat Bilimi ve Teknolojisi. Ankara: Gıda Teknolojileri Derneği Yayınlanı, No:15.

Akrayi, H. F. S. (2012). Antibacterial Effect of Seed Extracts of Cardamom (Elettaria cardamomum) against Staphylococcus aureus and Proteus mirabilis. Tikrit Journal of Pure Science, 17(2), 1813-1662. Retrieved from http:/ $/$ www.iasj.net/iasj?func=fulltext\&aId $=62089$

Ali, B. H., \& Blunden, G. (2003). Pharmacological and toxicological properties of Nigella sativa. Phytotherapy Research, 17(4), 299-305. https://doi.org/10.1002/ptr.1309

Anonymous. (2017). Baharat Tarihçesi. Retrieved March 10, 2017, from http://www.aksubaharat.com/baharatin-tarihcesi.php

Anwar, F., Abbas, A., Alkharfy, K. M., \& Gilani, A.-H. (2016). Cardamom (Elettaria cardamomum Maton) Oils. In Essential Oils in Food Preservation, Flavor and Safety (pp. 295-301). Elsevier. https://doi.org/10.1016/B978-0-12-416641-7.00033-X

Aydın, Ö. (2011). Tarçn, Kimyon Ve Sumak Adl Baharat Türlerinden Elde Edilen Su, Etanol-Su, Metanol Ve Kloroform Ekstraktlarmm İn Vitro Antioksidant Özelliklerinin Belirlenmesi. Atatürk Üniversitesi, Sağllk Bilimleri Enstitüsü, Yüksek Lisans Tezi.

Aydın, S., Öztürk, Y., \& Başer, K. H. C. (1993). Ege Yöresinde Yetişen Origanum onites L. (İzmir Kekiği) Üzerinde Etnofarmakolojik Araştırmalar. In X. Bitkisel İlaş Hammaddeleri Toplantısı. İzmir 20-22 May1s.

Babaoğlu, M. (2006). Dünya'da ve Türkiye'de Aspir Bitkisinin Tarihi, Kullanım Alanları ve Önemi. Retrieved March 9, 2017, from http:/ / arastirma.tarim.gov.tr/ttae/Sayfalar/Detay.aspx?SayfaId $=58$

Babaoğlu, M. (2014). Aspir Bitkisi ve Tarım. Retrieved March 9, 2017, from http://arastirma.tarim.gov.tr/ttae/Sayfalar/Detay.aspx?SayfaId=59

Baghalian, K., Sheshtamand, M. S., \& Jamshidi, A. H. (2010). Genetic variation and heritability of agromorphological and phytochemical traits in Iranian saffron (Crocus sativus L.) populations. Industrial Crops and Products, 31(2), 401-406. https://doi.org/10.1016/j.indcrop.2009.12.010

Baranska, M., Schulz, H., Rosch, P., Strehle, M. A., \& Popp, J. (2004). Identification of secondary metabolites in medicinal and spice plants by NIR-FT-Raman microspectroscopic mapping. The Analyst, 129(10), 926-30. https://doi.org/10.1039/b408933m

Basak, S. S., \& Candan, F. (2013). Effect of Laurus nobilis L. Essential Oil and its Main Components on $\alpha-$ glucosidase and Reactive Oxygen Species Scavenging Activity. Health Services Iranian Journal of Pharmaceutical Research, 12(2), 367-379. Retrieved from https://www.ncbi.nlm.nih.gov/pmc/articles/PMC3813252/pdf/ijpr-12-367.pdf

Batur, M. (2015). Kozak Yöresi Fistıkçamı (Pinus pinea L.) ormanlarında fistık verimi ile artım ve bazı meteorolojik olaylar arasındaki ilişkiler. Ormancllk. Arasttrma Dergisi Journal of Forestry Research, 1(12), 29-34. https://doi.org/10.17568/oad.89717

Baytop, T. (1984). Türkiye'de Bitkiler İle Tedavi. İstanbul: İstanbul Üniversitesi, Eczacılık Fakültesi Yayınları No:40.

Baytop, T. (1994). Türkçe Bitki Adlarn Söəlügü. İstanbul: Türk Dil Kurumu Yayınları, No: 578. 
Yıkmış, S., Sağlam, K., \& Yetim, A. (2017). The examination of spices used in the Ottoman palace cuisine. Journal of Human Sciences, 14(1), 1000-1016. doi:10.14687/ihs.v14i1.4508

Baytop, T. (1999). Türkiye'de bitkilerle tedavi (2nd ed.). İstanbul: Nobel Tip Kitabevleri.

Binici, A. (2002). Baharat Değerlendirme Raporu. Ankara.

Blumenthal, M. (2000). Herbal medicine: expanded Commission E monographs. Integrative Medicine Communications.

Blumenthal, M., Goldberg, A., \& Brinckmann, J. (2000). Herbal medicine: expanded Commission E monographs. Boston: Integrative Medical Communications.

Botsoglou, N. A., Christaki, E., Fletouris, D. J., Florou-Paneri, P., \& Spais, A. B. (2002). The effect of dietary oregano essential oil on lipid oxidation in raw and cooked chicken during refrigerated storage. Meat Science, 62(2), 259-265. https://doi.org/10.1016/S0309-1740(01)00256-X

Bozkurt, Y., Yaltır1k, F., \& Özdönmez, M. (1982). Türkiye de Orman Yan Ürünleri. İstanbul Üniversitesi Orman Fakakültesi Yaymlar, NO: 2845/302, İstanbul.

Boztok, Ş., \& Zeybek, U. (2003). Pistacia Cinsine Dahil Bazı Doğal Bitkilerin Sakız Kalitesi Açısından İrdelenmesi, Gıda ve İlaç Sanayinde Değerlendirilmesi Üzerine Araştırma. Ege Üniversitesi Tarmmsal Uygulama ve Arastorma Merkezi, 1-17. Retrieved from https://view.officeapps.live.com/op/view.aspx?src=http://agr.ege.edu.tr/files/depo/teknik_brosu r/Sakiz.doc

Büÿ̈̈k Larousse Sǫ̈lïk ve Ansiklopedisi. (1986) (12th ed.). Milliyet Gazetesi İnterpress Basın ve Yayınları.

B̈̈ÿük Larousse Sözlïk ve Ansiklopedisi. (1986) (5th ed.). Milliyet Gazetesi İnterpress Basın ve Yayınları.

B̈̈ÿ̈̈k Larousse Sözlïk ve Ansiklopedisi. (1986) (16th ed.). Milliyet Gazetesi İnterpress Basın ve Yayınlar1.

Chaieb, K., Hajlaoui, H., Zmantar, T., Kahla-Nakbi, A. Ben, Rouabhia, M., Mahdouani, K., \& Bakhrouf, A. (2007). The chemical composition and biological activity of clove essential oil,Eugenia caryophyllata (Syzigium aromaticum L. Myrtaceae): a short review. Phytotherapy Research, 21(6), 501-506. https://doi.org/10.1002/ptr.2124

Chaudhry, N. M. A., \& Tariq, P. (2006). Bactericidal activity of black pepper, bay leaf, aniseed and coriander against oral isolates. Pakistan Journal of Pharmaceutical Sciences, 19(3), 214-8. Retrieved from http://www.ncbi.nlm.nih.gov/pubmed/16935829

Chen, G., \& Liu, B. (2016). Cellulose sulfate based film with slow-release antimicrobial properties prepared by incorporation of mustard essential oil and $\beta$-cyclodextrin. Food Hydrocolloids, 55, 100-107. https://doi.org/10.1016/j.foodhyd.2015.11.009

Çelebi, C.. (2010). Fesleğenin (Ocimum basilicum) Fenolik Madde Dağglamı ve Antioksidan Aktivitesinin Belirlenmesi. Ankara Üniversitesi Fen Bilimleri Enstitüsü, Yüksek Lisans Tezi, Ankara.

Çetin, T. (2003). Doğal Ortam Ekonomik Faaliyet İlişkisine Bir Örnek Kozak Yöresi Bergama. Gą̧i Üniversitesi Gari Ë̆itim Fakültesi Dergisi, 23(1). https://doi.org/10.17152/GEFD.46347

Dalby, A. (2000). Dangerous tastes: spices in world history. University of California Press. Retrieved from http:/ /www.ucpress.edu/book.php?isbn=9780520236745

Damjanovic, B., Lepojevic, Z., Zivkovic, V., \& Tolic, A. (2005). Extraction of fennel ( Mill.) seeds with supercritical CO: Comparison with hydrodistillation. Food Chemistry, 92(1), 143-149. https://doi.org/10.1016/j.foodchem.2004.07.019

Davis, P. H. (1988). Flora of Turkey and the East Aegean Islands / 10 Supplement. University Press.

Derosa, G., Maffioli, P., \& Sahebkar, A. (2016). Piperine and Its Role in Chronic Diseases. In Advances in experimental medicine and biology (Vol. 928, pp. 173-184). https://doi.org/10.1007/978-3-319-41334$1 \_8$

Dhuley, J. N., Safdar, M., Khan, M. M. A., Khattak, K. N., \& Anderson, R. A. (1999). Anti-oxidant effects of cinnamon (Cinnamomum verum) bark and greater cardamom (Amomum subulatum) seeds in rats fed high fat diet. Indian Journal of Experimental Biology, 37(3), 238-42. https://doi.org/10.1073/PNAS.94.18.9660

Doğan, A., \& Akgün, A. (1987). Kişniş (Coriandrum sativum L.) Üretimi, Bileşimi ve Kullanımı. Türk Tarmm ve Ormancllk Dergisi, 11(2), 326-333.

Doğramac1, S., \& Arabac1, O. (2010). Organik ve İnorganik Gübre Uygulamalarının Anason (Pimpinella anisum L.) Çeşit ve Ekotiplerinin Verim ve Verim Öğreleri Üzerine Etkisi. ADÜ Ziraat Fakülttesi Dergisi, 7(2), 103-109.

Erken, S., Sönmez, Ç., Sancaktaroğlu, S., \& Bayram, E. (2015). Effects of different plant densities on yield and quality characteristics of Sweet Basil (Ocimum basilicum L.). Ege Üniversitesi Ziraat Fakïltesi Dergisi, 46(3), 165-173. 
Yıkmış, S., Sağlam, K., \& Yetim, A. (2017). The examination of spices used in the Ottoman palace cuisine. Journal of Human Sciences, 14(1), 1000-1016. doi:10.14687/ihs.v14i1.4508

Ertaş, Y., \& Gezmen Karadağ, M. (2013). Sağlıklı Beslenmede Türk Mutfak Kültürünün Yeri. Gümmüshane Üniversitesi Sağhl. Bilimleri Dergisi, 2(1), 117-136. Retrieved from http://dergipark.ulakbim.gov.tr/gumussagbil/article/view/5000003585/5000004099

Ertürk, R., Çelik, C., Kaygusuz, R., \& Aydın, H. (2010). Ticari olarak satılan kekik ve nane uçucu yağlarının antimikrobiyal aktiviteleri. Cumburiyet Medical Journal, 32(4), 281-286.

Erylmaz, T., Cesur, C., Yeşilyurt, M. K., \& Aydın, E. (2014). Aspir (Carthamus tinctorius L.), Remzįbey-05 Tobum Yağ̀ Metil Esteri: Potansiyel Diz̨el Motor Uygulamalar için Yakıt Özellikleri. Turkish Journal of Agricultural and Natural Science (Vol. 1). Retrieved from http://www.turkjans.com/ojs/index.php/TJANS/article/view/22

Evren, M., \& Tekgüler, B. (2011). Uçucu Yagların Antimikrobiyel Özellikleri. Elektronik Mikrobijoloji Dergisi TR (Eski Adr: OrLab On-Line Mikrobiyoloji Dergisi, 9(3), 28-40.

Fakılı, O. (2010). Türkiye'de Kekike Adı İle Amulan Bitkiler Konusunda Yapılan Callsmalarn Envanteri. Çukurova Üniversitesi, Fen Bilimleri Enstitüsü, Tarla Bitkileri Anabilim Dalı, Adana.

Ghasemzadeh, A., Ashkani, S., Baghdadi, A., Pazoki, A., Jaafar, H., \& Rahmat, A. (2016). Improvement in Flavonoids and Phenolic Acids Production and Pharmaceutical Quality of Sweet Basil (Ocimum basilicum L.) by Ultraviolet-B Irradiation. Molecules, 21(9), 1203. https://doi.org/10.3390/molecules21091203

Gill, A. O., \& Holley, R. A. (2003). Interactive inhibition of meat spoilage and pathogenic bacteria by lysozyme, nisin and EDTA in the presence of nitrite and sodium chloride at 24 degrees C. International Journal of Food Microbiology, 80(3), 251-9. Retrieved from http://www.ncbi.nlm.nih.gov/pubmed/12423927

Gilles, M., Zhao, J., An, M., \& Agboola, S. (2010). Chemical composition and antimicrobial properties of essential oils of three Australian Eucalyptus species. Food Chemistry, 119(2), 731-737. https://doi.org/10.1016/j.foodchem.2009.07.021

Gök, A., \& Tuna, H. (2013). Turizm Pazarlaması Açısından Malatya İlinin Potansiyelinin Belirlenmesi. KMÜ Sosyal ve Ekonomik. Arastirmalar Dergisi , 15(24), 1-11.

Gönültaş, O., \& Balaban Uçar, M. (2012). Fistıkçamı (Pinus pinea) Kabuğunun Tanen Bileşimi. Kabramanmaras Sütçü Imam Üniv. Doğa Bil. Der. Özel Sayı, 80-84.

Gruenwald, J., Brendler, T., \& Jaenicke, C. (2004). PDR for Herbal Medicines (3rd ed.). Medical Economics Company, New Jersey.

Gürpınar Y. (2012). Tarbun Bitkisinin (Artemissia drancunculus L.) Wistar Albimo Ratlarda Olusturmus Akut Toksik Hasarna Karşı Koruyucu ve Tedavi Edici Etkisinin Arasstrmlması. Gaziantep Üniversitesi Fen Bilimleri Enstitüsü, Biyoloji Bölümü, Yüksek Lisans Tezi.

Gürson, O., \& Özçelikay, G. (2005). Tarçın'n Tarih Boyunca ve Günümüzdeki Kullanımı. Ankara Universitesi Osmanl Taribi Arastrtrma ve Uygulama Merkerzi Dergisi, 171-183. https://doi.org/10.1501/ankara-5106

Gürsoy, O. V., \& Kahraman, G. (2004). Anadolu'da Diş ve Diş Eti ile İlgili Hastalıkların Tedavisinde Halk Arasında Yaygın Olarak Kullanılan Bitkiler, Kullanım Şekilleri ve Bitkisel Özellikleri. Cumburiyet Üniversitesi Diș Hekimlĭ̈i Fakültesi Dergisi, 7(1), 63-67.

Hall, C. (2016). Overview of the Oilseed Safflower (Carthamus tinctorius L.). In Reference Module in Food Science. Elsevier. https://doi.org/10.1016/B978-0-08-100596-5.00030-5

Hall, C. M., \& Mitchell, R. (2001). Wine and Food Tourism. (N. Douglas, N. Douglas, \& R. Derrett, Eds.) (1st ed.). John Wiley \& Sons Australia.

Hassanzadeh, M. K., Tayarani Najaran, Z., Nasery, M., \& Emami, S. A. (2016). Tarragon (Artemisia dracunculus L.) Oils. In Essential Oils in Food Preservation, Flavor and Safety (pp. 813-817). https://doi.org/10.1016/B978-0-12-416641-7.00092-4

Hinneburg, I., Damien Dorman, H. J., \& Hiltunen, R. (2006). Antioxidant activities of extracts from selected culinary herbs and spices. Food Chemistry, 97(1), 122-129. https://doi.org/10.1016/j.foodchem.2005.03.028

Ietswaart, J. H. (1980). A taxonomic revision of the genus Origanum (Labiatae). Leiden university press. Retrieved from http://www.springer.com/la/book/9789060214633

İzzaddeen, S. İ. (2015). Süt emme dönemindeki siyah alaca buzağglarda defne uçucu yağz (Laurus nobilis L.) kullanmmmn performans, kan ve deşkı parametrelerine etkisi. Kahramanmaraş Sütçü İmam Üniversitesi,Fen Bilimleri Enstitüsü ,Zootekni Anabilim Dalı. 
Yıkmış, S., Sağlam, K., \& Yetim, A. (2017). The examination of spices used in the Ottoman palace cuisine. Journal of Human Sciences, 14(1), 1000-1016. doi:10.14687/jhs.v14i1.4508

Jakribettu, R. P., Boloor, R., Bhat, H. P., Thaliath, A., Haniadka, R., Rai, M. P., .. Baliga, M. S. (2016). Ginger (Zingiber officinale Rosc.) Oils. In Essential Oils in Food Preservation, Flavor and Safety (pp. 447454). Elsevier. https://doi.org/10.1016/B978-0-12-416641-7.00050-X

Janahmadi, M., Niazi, F., Danyali, S., \& Kamalinejad, M. (2006). Effects of the fruit essential oil of Cuminum cyminum Linn. (Apiaceae) on pentylenetetrazol-induced epileptiform activity in F1 neurones of Helix aspersa. Journal of Ethnopharmacology, 104(1-2), 278-282. https://doi.org/10.1016/j.jep.2005.09.019

Juliani, H. R., Kapteyn, J., Jones, D., Koroch, A. R., Wang, M., Charles, D., \& Simon, J. E. (2006). Application of near-infrared spectroscopy in quality control and determination of adulteration of African essential oils. Phytochemical Analysis: PCA, 17(2), 121-8. Retrieved from http://www.ncbi.nlm.nih.gov/pubmed/16634289

Kalus, U., Pruss, A., Bystron, J., Jurecka, M., Smekalova, A., Lichius, J. J., \& Kiesewetter, H. (2003). Effect ofNigella sativa (black seed) on subjective feeling in patients with allergic diseases. Phytotherapy Research, 17(10), 1209-1214. https://doi.org/10.1002/ptr.1356

Kaplan, H. (2005). Zencefilin (Zingiber officinale Roscoe) bitkisel Özellikleri ve Yetiştiriciliği. Batı Akdeniz Tarmsal Arașturma Enstitïsï. Retrieved from http://batem.gov.tr/yayinlar/derim/2005/201-09 (1).pdf

Kara, T. (2016). Prbtyya çiğ ve haşlanmıs kişniş (Coriandrum sativum L.) katularak üretilen beyaz, peynirin kalitesi. Atatürk Üniversitesi / Fen Bilimleri Enstitüsü / Gıda Mühendisliği Anabilim Dalı, Yüksek Lisans Tezi.

Karakuzu, E. (2015). Fesleğen (Ocimum basilicum L) tohumunun ekim olanaklar. Adnan Menderes Üniversitesi, Fen Bilimleri Enstitüsü, Aydın.

Karaoğul, E., Ertaş, M., Altuntaş, E., \& Alma, M. . (2011). Karadeniz ve Akdeniz Bölgesinde Yetişen Defne (Laurus nobilis)'nin Kimyasal İçeriği. In I. Ulusal Akdeniz Orman ve Çevre Sempozyumu (pp. 74-77). Kahramanmaraş. Retrieved from http://dergipark.ulakbim.gov.tr/public/journals/1075/docs/OzelSayilar/MuhendislikBilimleri/PD F/12.Karadeniz ve Akdeniz Bölgesinde Yetişen Defne (Laurus nobilis)'nin Kimyasal İçeriği_E. Karaoğul,

Karsha, P. V., \& Lakshmi, O. B. (2010). Antibacterial activity of black pepper (Piper nigrum Linn.) with special reference to its mode of action on bacteria. Indian Journal of Natural Products and Resources, 1(2), 213-215.

Kaya, K., Yılmaz, G., \& Telci, İ. (2000). Farklı Zamanlarda Ekilen Kişniş (Coriandrum sativum L.) Populasyonlarının Agronomik ve Teknolojik Özellikleri. Turk J Agric For, 24, 355-364. Retrieved from http://journals.tubitak.gov.tr/agriculture/issues/tar-00-24-3/tar-24-3-7-9901-14.pdf

Kerekes, E.-B., Vidács, A., Török, J. J., Gömöri, C., Petkovits, T., Chandrasekaran, M., ... Krisch, J. (2016). Anti-listerial effect of selected essential oils and thymol. Acta Biologica Hungarica, 67(3), 333-343. https://doi.org/10.1556/018.67.2016.3.10

Kızıl, S., Toncer, O., Diraz, E., \& Karaman, S. (2015). Varation of Agronomical Characteristics and Essential Oil Components of Zahter (Thymbra spicata L. var. spicata) Populations in Semi-Arid Climatic Conditions. Turk J Field Crops, 20(2), 242-251. https://doi.org/10.17557/tjfc.46517

Kocabıyı, H., \& Demirtürk, B. S. (2008). Nane Yapraklarının İnfrared Radyasyonla Kurutulması. Tekirdağ Ziraat Fakïltesi Dergisi, 5(3), 239-246.

Konuklugil, B., \& Özçelikay, G. (2004). Zencefilin Tarih boyunca Önemi ve Günümüzdeki Kullanımı. Retrieved March 9, 2017, from http://dergiler.ankara.edu.tr/dergiler/19/1273/14665.pdf

Kosar, M., Bozan, B., Temelli, F., \& Baser, K. H. C. (2007). Antioxidant activity and phenolic composition of sumac (Rhus coriaria L.) extracts. Food Chemistry, 103(3), 952-959. https://doi.org/10.1016/j.foodchem.2006.09.049

Kozak, N. (2006). Turizm Pazarlaması. Ankara: Detay Yayıncillk.

Lee, K.-G., \& Shibamoto, T. (2001). Antioxidant property of aroma extract isolated from clove buds [Syzygium aromaticum (L.) Merr. et Perry]. Food Chemistry, 74(4), 443-448. https://doi.org/10.1016/S0308-8146(01)00161-3

Maggi, L., Carmona, M., Zalacain, A., Kanakis, C. D., Anastasaki, E., Tarantilis, P. A., ... Alonso, G. L. (2010). Changes in saffron volatile profile according to its storage time. Food Research International, 43(5), 1329-1334. https://doi.org/10.1016/j.foodres.2010.03.025 
Yıkmış, S., Sağlam, K., \& Yetim, A. (2017). The examination of spices used in the Ottoman palace cuisine. Journal of Human Sciences, 14(1), 1000-1016. doi:10.14687/ihs.v14i1.4508

Marx, W., McCarthy, A. L., Ried, K., McKavanagh, D., Thomson, D., Sali, A., \& Isenring, L. (2014). Effects of ginger on motion sickness and gastric slow-wave dysrhythmias induced by circular vection. BMC Complementary and Alternative Medicine, 14(1), 134. https://doi.org/10.1152/ajpgi.00164.2002

Mascarello, C., Fascella, G., Zizzo, G. ., Mantovani, E., \& Ruffoni, B. (2007). In Vivo and In Vitro Propagation of Pistacia lentiscus L. Acta Hort. (ISHS) 764 , 299-306. Retrieved from http://www.ishs.org/ishs-article/764_41

Mattson, T. E., Johny, A. K., Amalaradjou, M. A. R., More, K., Schreiber, D. T., Patel, J., \& Venkitanarayanan, K. (2011). Inactivation of Salmonella spp. on tomatoes by plant molecules. International Journal of Food Microbiology, 144(3), 464-468. https://doi.org/10.1016/j.ijfoodmicro.2010.10.035

Mcgimpsey, J. A., Douglas, M. H., \& Wallace, A. R. (1997). New Zealand Journal of Crop and Horticultural Science Evaluation of saffron (Crocus sativus L.) production in New Zealand Evaluation of saffron (Crocus sativus L.) production in New Zealand. New Zealand Journal of Crop and Horticultural Science, 2525(2), 159-168. https://doi.org/10.1080/01140671.1997.9514002

McIntosh, F. M., Newbold, C. J., Losa, R., Williams, P., \& Wallace, R. J. (2000). Effects of Essential Oils on Rumen Fermentation. Reproduction Nutrition Development, 40(2), 221-222.

Mohammad Reza, S., Hamideh, M., \& Zahra, S. (2015). The Nociceptive and Anti-Inflammatory Effects of Artemisia dracunculus L. Aqueous Extract on Fructose Fed Male Rats. Evidence-Based Complementary and Alternative Medicine, 2015, 1-5. https://doi.org/10.1155/2015/895417

Mündel, H. H. (2008). Major achievements in safflower breeding and future challenges. In 7. International Safflower Conference. Wagga Wagga, Australia: Australian Oilseeds Federation. Retrieved from http://www.australianoilseeds.com/conferences_workshops/international_safflower_conference2/ conference_proceedings/keynote

Nas, S., Gökalp, H. Y., \& Ünsal, M. (1992). Bitkisel Yağ Teknolojisi. Erzurum: Atatürk Üniversitesi Yayınları No: 723. Ziraat Fakültesi No: 312. Ders Kitaplar1 Serisi No: 64.

Nasar-Abbas, S. M., \& Halkman, A. K. (2004). Antimicrobial effect of water extract of sumac (Rhus coriaria L.) on the growth of some food borne bacteria including pathogens. International Journal of Food Microbiology, 97(1), 63-69. https://doi.org/10.1016/j.ijfoodmicro.2004.04.009

Olaimat, A. N., \& Holley, R. A. (2016). Inhibition of Listeria monocytogenes on cooked cured chicken breasts by acidified coating containing allyl isothiocyanate or deodorized Oriental mustard extract. Food Microbiology, 57, 90-95. https://doi.org/10.1016/j.fm.2016.02.001

Öz, S. (2013). Deneysel böbrek, iskemi/ reperfüsyon hasarnda pelargonium sidoidesin etkileri. Trakya Üniversitesi, Sağlık Bilimleri Enstitüsü, Edirne.

Özbek, H., Cengiz, N., Him, A., Uğraş, S., Özgökçe, F., \& Erdoğan, E. (2016). Yüksek Kolesterollü Diyetle Beslenen Sıçanlarda Thymus fallax F. (kekik) Yapraklarının Kan Kolesterol Seviyesi Üzerine Etkisi. Van Thp Dergisi, 13(3), 71-77.

Özcan, M. M., \& Chalchat, J. C. (2006). Chemical composition and antifungal effect of anise (Pimpinella anisum L.) fruit oil at ripening stage. Annals of Microbiology, 56(4), 353-358. https://doi.org/10.1007/BF03175031

Özgüven, M., \& Kırıcı, S. (1999). Farklı ekolojilerde nane (Mentha) türlerinin verim ile uçucu yağ oran ve bileşenlerinin araştırilmas1. Turkish Journal of Agriculture and Forestry, 23(4), 465-472.

Özkanl, O., \& Tekin, A. R. (2006). Eski ve Yeni Mahsul Sumak Tanelerinin Su Soğurma zotermlerinin Modellenmesi. In Türkiye 9. Grda Kongresi (pp. 331-334). Bolu.

Pamuk, A. (1998). Sifalı Bitkiler Ansiklopedisi (1st ed.). İstanbul: stanbul: Pamuk Yayıncllk ve Matbaacilık.

Park, E. J., \& Pezzuto, J. M. (2002). Botanicals in cancer chemoprevention. Cancer Metastasis Reviens, 21(3-4), 231-55. Retrieved from http://www.ncbi.nlm.nih.gov/pubmed/12549763

Parthasarathy, V. A., \& Prasath, D. (2012). Cardamom. In Handbook of Herbs and Spices (2nd ed., pp. 131170). Elsevier. https://doi.org/10.1533/9780857095671.131

Pavela, R., Žabka, M., Bednář, J., Tř́ska, J., \& Vrchotová, N. (2016). New knowledge for yield, composition and insecticidal activity of essential oils obtained from the aerial parts or seeds of fennel (Foeniculum vulgare Mill.). Industrial Crops and Products, 83, 275-282. https://doi.org/10.1016/j.indcrop.2015.11.090 
Yıkmış, S., Sağlam, K., \& Yetim, A. (2017). The examination of spices used in the Ottoman palace cuisine. Journal of Human Sciences, 14(1), 1000-1016. doi:10.14687/ihs.v14i1.4508

Pilar Santamarina, M., Roselló, J., Giménez, S., \& Amparo Blázquez, M. (2016). Commercial Laurus nobilis L. and Syzygium aromaticum L. Merr. \&amp; Perry essential oils against post-harvest phytopathogenic fungi on rice. LWT - Food Science and Technology, 65, 325-332. https://doi.org/10.1016/j.lwt.2015.08.040

Prakash, B., Shukla, R., Singh, P., Mishra, P. K., Dubey, N. K., \& Kharwar, R. N. (2011). Efficacy of chemically characterized Ocimum gratissimum L. essential oil as an antioxidant and a safe plant based antimicrobial against fungal and aflatoxin B1 contamination of spices. Food Research International, 44(1), 385-390. https://doi.org/10.1016/j.foodres.2010.10.002

Price, R., Palmer, J., \& Al-Shehbaz, I. (1994). Systematic relationships of Arabidopsis: a molecular and morphological perspective pp. 7-19 in Arabidopsis. (E. Meyerowitz \& C. Somerville, Eds.). Cold Spring Harbor Laboratory Press, Cold Spring Harbor, NY.

Quesada, J., Sendra, E., Navarro, C., \& Sayas-Barberá, E. (2016). Antimicrobial Active Packaging including Chitosan Films with Thymus vulgaris L. Essential Oil for Ready-to-Eat Meat. Foods, 5(3), 57. https://doi.org/10.3390/foods5030057

Rafiq, R., Hayek, S., Anyanwu, U., Hardy, B., Giddings, V., Ibrahim, S., .. Kang, H. (2016). Antibacterial and Antioxidant Activities of Essential Oils from Artemisia herba-alba Asso., Pelargonium capitatum $\times$ radens and Laurus nobilis L. Foods, 5(2), 28. https://doi.org/10.3390/foods5020028

Rajamurugan, R., Selvaganabathy, N., Kumaravel, S., Ramamurthy, C., Sujatha, V., \& Thirunavukkarasu, C. (2012). Polyphenol contents and antioxidant activity of Brassica nigra (L.) Koch. leaf extract. Natural Product Research, 26(23), 2208-2210. https://doi.org/10.1080/14786419.2011.637215

Randhawa, M. A., \& Alghamdi, M. S. (2011). Anticancer activity of Nigella sativa (black seed)—a review —. The American Journal of Chinese Medicine, 39(6), 1075-1091. https://doi.org/10.1142/S0192415X1100941X

Ruberto, G., Baratta, M. T., Sari, M., \& Kaâbeche, M. (2002). Chemical composition and antioxidant activity of essential oils from Algerian Origanum glandulosum Desf. Flavour and Fragrance Journal, 17(4), 251 254. https://doi.org/10.1002/ffj.1101

Sari, Y., \& Kozak, M. (2005). Turizm Pazarlanmasına İnternetin Etkisi:Destinasyon Web Siteleri İçin Bir Model Önerisi. Akdeniz I.I.I.B.F. Dergisi, (9), 248-271.

Shylaja, M. R., \& Peter, K. . (2006). Handbook of Herbs and Spices. (K. V. Peter, Ed.) (3rd ed.). Washington, USA: CRC Press.

Smith-Palmer, A., Stewart, J., \& Fyfe, L. (2002). Inhibition of listeriolysin O and phosphatidylcholine-specific production in Listeria monocytogenes by subinhibitory concentrations of plant essential oils. Journal of Medical Microbiology, 51(7), 567-608. https://doi.org/10.1099/0022-1317-51-7-567

Srinivasan, K. (2007). Black Pepper and its Pungent Principle-Piperine: A Review of Diverse Physiological Effects. Critical Reviews in Food Science and Nutrition, 47(8), 735-748. https://doi.org/10.1080/10408390601062054

Şafak, İ., \& Okan, T. (2004). Kekik, Defne ve Çam Fistiğinin Üretimi ve Pazarlaması. Journal of DOA, 10, 101-129. Retrieved from http://yayin.ogm.gov.tr/yaydepo/696.pdf

Şanlı, A., Karadoğan, T., \& Daldal, H. (2012). Burdur'da Tarımı Yapılan Bazı Umbelliferae Türlerinin Uçucu Yağ Oranı ve Bileşenlerinin Belirlenmesi. Süleyman Demirel Üniversitesi Ziraat Fakültesi Dergisi , 7(1), 27-31.

Tayar, M. (2012). Baharatın Gizemli Tarihi. Retrieved March 10, 2017, from http://www.dunyagida.com.tr/kose-yazisi/baharatin-gizemli-tarihi/1026

Thippeswamy, N. B., \& Naidu, K. A. (2005). Antioxidant potency of cumin varieties—cumin, black cumin and bitter cumin—on antioxidant systems. European Food Research and Technology, 220(5-6), 472-476. https://doi.org/10.1007/s00217-004-1087-y

Tirapelli, C. R., de Andrade, C. R., Cassano, A. O., De Souza, F. A., Ambrosio, S. R., da Costa, F. B., \& de Oliveira, A. M. (2007). Antispasmodic and relaxant effects of the hidroalcoholic extract of Pimpinella anisum (Apiaceae) on rat anococcygeus smooth muscle. Journal of Ethnopharmacology, 110(1), 23-29. https://doi.org/10.1016/j.jep.2006.08.031

Turgis, M., Han, J., Caillet, S., \& Lacroix, M. (2009). Antimicrobial activity of mustard essential oil against Escherichia coli O157:H7 and Salmonella typhi. Food Control, 20(12), 1073-1079. https://doi.org/10.1016/j.foodcont.2009.02.001

Türkan, Ş., Malyer, H., Özaydın, S., \& Tümen, G. (2006). Ordu İli ve Çevresinde Yetişen Bazı Bitkilerin Etnobotanik Özellikleri. SDÜ Fen Bilimleri Enstitïï̈ Dergisi, 10(2), 162-166. 
Yıkmış, S., Sağlam, K., \& Yetim, A. (2017). The examination of spices used in the Ottoman palace cuisine. Journal of Human Sciences, 14(1), 1000-1016. doi:10.14687/jhs.v14i1.4508

Uzun, A. (2007). Labiatae (ballibabagiller) familyasina mensup ilaç ve baharat olarak kullanulabilecek fesleğen (Ocimum basilicum L.) ve kekike (Origanum vulgare L.) türlerinin bą̧ özelliklerinin tespiti üzerine bir araștorma. Ondokuz Mayıs Üniversitesi, Fen Bilimleri Enstitüsü, Samsun.

Uzun, A., Kevseroğlu, K., Özçelik, H., \& Yılmaz, S. (2012). Karadeniz Bölgesi İçin Geliştirilen Rezene (Foeniculum vulgare Mill. var. Dulce) Hatlarının Verim Uçucu Yağ Oranlarının Stabilite Analizi. Anadolu Tarm Bilimleri Dergisi, 27(1), 23-30. https://doi.org/10.7161/anajas.2012.v27n1.2330

Üner, Y., Aksu, H., \& Ergün, Ö. (2000). Baharatın Çeşitli Mikroorganizmalar Üzerine Etkileri. Istanbul Üniversitesi Veteriner Fakültesi Dergisi, 26, 1-10.

Ünlü, S., \& Aysan, Y. (2016). Sardunya (Pelargonium spp.) bakteriyel yanıklı etmeni Xanthomonas axonopodis pv. pelargonii'nin biyolojik mücadelesi üzerine araştırmalar. Türkìye Biyolojik Mücadele Dergisi, 2(1), 25-38.

Vurdu, H., Şaltu, Z., \& Ayan, S. (2002). Safran (Crocus sativus L.)’un yetiştirme tekniği. Gaẓi Üniversitesi, Kastamonu Orman Fakültesi Dergisi, 2(2), 175-187.

Wagner, H., \& Bladt, S. (1996). Plant Drug Analysis. Berlin, Heidelberg: Springer Berlin Heidelberg. https://doi.org/10.1007/978-3-642-00574-9

Yaldız, G., Kılınç, E., \& Ülküsever, S. (2010). Rize’nin bazı ilçelerinde (pazar, ardeşen, çayeli) yaşayan ailelerin baharat kullanım alışkanlıklanı üzerine bir araştırma. In Ulusal Meslek Yüksekokullar Öğgenci Sempozyumu Kitab (pp. 1-7). Retrieved from http://www.hurriyet.com.tr/

Yücedağ, C., Gültekin, H. C., \& Pırlak, İ. T. (2010). Sera ve açık alanda sumak (rhus coriaria 1.) tohumları çimlenmesi üzerine ekim zamanı ve örtülemenin etkileri. Turkish Journal of Forestry, 1, 9-15. Retrieved from https://www.mysciencework.com/publication/show/e02509a8a9c3519111687ed3f5e8a951

Zaika, L. L. (2007). Spices and herbs: their antimicrobial activity and its determination. Journal of Food Safety, 9(2), 97-118. https://doi.org/10.1111/j.1745-4565.1988.tb00511.x

Zeybek, N., \& Zeybek, U. (1994). Farmasötik Botanik. İzmir: Ege Üniversitesi, Eczacilık Fak. Yayın No: 2. 